\title{
A new species of the genus Canthon Hoffmannsegg (Coleoptera, Scarabaeidae, Scarabaeinae, Deltochilini) from central Brazil
}

\author{
Fernando Z. Vaz-de-Mello ${ }^{1,3}$; Luis Gabriel de Oliveira Albuquerque Nunes ${ }^{1,4}$ \& Vinícius da Costa-Silva ${ }^{1,2}$ \\ 1 Universidade Federal de Mato Grosso (UFMT), Instituto de Biociências (IB), Centro de Biodiversidade, Laboratório de Scarabaeoidologia. \\ Cuiabá, MT, Brasil. \\ 2 Universidade Estadual de Campinas (UNICAMP), Instituto de Biologia (IB), Departamento de Biologia Animal, Laboratório de Entomologia \\ Integrativa (LEI). Campinas, SP, Brasil. ORCID: http://orcid.org/0000-0002-4556-3793. E-mail: silvavinicius92@gmail.com \\ ${ }^{3}$ ORCID: http://orcid.org/0000-0001-9697-320X. E-mail: vazdemello@gmail.com \\ ${ }^{4}$ ORCID: http://orcid.org/0000-0001-5168-3161. E-mail: luis.gabriel.bio@gmail.com
}

\begin{abstract}
A new species of Canthon is described, illustrated and the morphological similarities with related species are discussed. The species Canthon cleidecostae was named after Dr. Cleide Costa a great beetles specialist. The subgeneric category of species is considered incertae sedis until the taxonomic revision of the genus Canthon is fully addressed. Also, we provide a key for genera, subgenera and isolated species-groups that can be confused with the genus Canthon.
\end{abstract}

Key-Words. Dung beetles; South America; Subgenera key; Taxonomy.

\section{INTRODUCTION}

The genus Canthon Hoffmannsegg, 1817 is one of the most diverse groups in Scarabaeinae, comprising c. 180 described valid species (Halffter \& Martínez, 1977; Schoolmeesters, 2018; Vieira et al., 2019) belonging to nine subgenera (Halffter \& Martínez, 1977). Besides that, there are nearly 32 described species and subspecies still considered as incertae sedis due to absence of diagnostic characteristics that can be used to classify these species into a subgenus of Canthon (Halffter \& Martínez, 1977; Vaz-de-Mello et al., 2011; Nunes et al., 2018; Cupello \& Vaz-de-Mello, 2018; Vieira et al., 2019).

Here, we present a new species to science belonging to the genus Canthon. Considering the plasticity of characters of this group and the clear artificiality of many of its internal divisions, we decided not to include Canthon cleidecostae sp. nov. in any subgeneric position. Thus, to avoid the taxonomic complication we will keep Canthon cleidecostae sp. nov. as incertae sedis. is used to a new line on a same label. Label colour or other additional information is given in brackets ([...]). Type specimens are deposited at Seção de Entomologia da Coleção Zoológica da Universidade Federal do Mato Grosso, Cuiabá, Brazil (CEMT). Morphological analysis and comparisons were conducted using a Leica stereomicroscope model S8AP0. All photographs were made using a stereomicroscope Leica model m205C (7.8X-160.0X) with image capture system MC190 HD.

The methods of extraction and preservation of internal sac follow Zunino (1978). The external morphology was based on Edmonds (1972) and Tarasov \& Génier (2015). For the microsculpture description we follow the terminology proposed by Harris (1979). All length measurements mentioned in the description are in millimetres $(\mathrm{mm})$.

Abbreviations used in the description: $\mathbf{A x}=$ axial sclerite; $\mathbf{F L P}=$ fronto-lateral peripheric sclerite; $\mathbf{M P}=$ medial peripheric sclerite; $\mathbf{S A}=$ subaxial sclerite; SRP = superior peripheric sclerite.

\section{MATERIAL AND METHODS}

For type material, labels are transcribed in verbatim in quotation marks ("..."). The single slash (/)

\section{RESULTS}

Note: The identification key presented here is an update to that presented by Vaz-de-Mello et al. 
(2011), since many genera have been modified from recent taxonomic revisions, such as the transfer of species of the genus Canthon for the genus Sylvicanthon Halffter \& Martínez, 1977 (and vice versa) (see Cupello \& Vaz-de-Mello, 2018); Scybalocanthon Martínez, 1948 species transferred to Canthon (Silva \& Valois, 2019); the genus Vulcanocanthon Pereira \& Martinez, 1960 was synonymyzed with Canthon (Vieira et al., 2019); in addition to the rearrangement of various Canthon species considered "incertae sedis" for well-defined groups such as Goniocanthon Pereira \& Martínez, 1956 and Pseudepilissus Martínez, 1954.

\section{Key to genera, subgenera and isolated species-groups easily confused with Canthon occurring in South America (beginning from couplet 90 in Vaz-de-Mello et al., 2011)}

1. Basal meso- and metatarsomeres short, length about one-half that of the second tarsomere, obliquely (nearly $45^{\circ}$ ) truncated apically (Vaz-de-Mello et al., 2011, fig. 155). Lateral borders of meso- and metatarsomeres parallel, forming a continuous border for all tarsi, overall shape of tarsomeres 2-4 quadrate to rectangular. Dorsal surface of mesotibiae with dense setae, not in line. Pygidium never separated from propygidium by transverse carina. Widespread in tropical forest areas. Scybalocanthon Martínez, 1948 (see Silva \& Valois, 2019) Length of basal meso- and metatarsomeres only slightly less than, or greater than, that of tarsomere 2; if much smaller, then nearly transversely truncated apically. Lateral borders of meso- and metatarsomeres separately divergently apically, the overall shape of tarsomeres 1-4 trapezoidal; dorsal surface of mesotibiae with setae arranged in line.

$2\left(1^{\prime}\right)$. Pygidial base covered by elytra; tips of elytra overhang base of pygidium (which is not separated from propygidium), not appressed to base. Pubescent dorsum with yellow to red spots on elytra. Sides of pronotum serrate. Bolivia, and maybe Brazil and Venezuela.

Canthonidia Paulian, 1938 (revision is needed, probably monospecific)

2'. Pygidial base completely exposed (but propygidium not exposed); tips of elytra not overhanging base of pygidium, appressed to pygidial base. Glabrous dorsum; if pubescent, then monocoloured. Sides of pronotum not serrate.

$3\left(2^{\prime}\right)$. Dorsum (especially prothorax) with irregular sculpturing (mosaic of smooth, sericeous and microgranular areas, irregular ill-defined elevations and depressions) or with well-defined prothoracic tubercles.

3'. Pronotum with evenly distributed sculpturing, at most with posteromedian depression, never with tubercles. Widespread, except Chile Canthon Hoffmannsegg, 1817 (if transverse teeth or carinae are present in the lateral face of mesotibia, then check Vaz-de-Mello et al., 2011, couplet 89) ......... 5

4(3). Protibiae truncated in straight angle at apex. Male with elongated $Y$-form expansion derived from clypeal teeth, female with clypeal teeth widely separated. Southernmost of Brazil (Rio Grande do Sul) and Argentina (Buenos Aires) ......... Xenocanthon Martínez, 1952 (monospecific, X. sericans (Schmidt, 1922))

4'. Protibiae obtusely truncated at the apex. Both male and female with similar clypeus, with teeth separated by V emargination. Chacoan depression, Cerrado, Orinoquía and Amazonia Anisocanthon Martínez \& Pereira, 1956 (under revision)

$5\left(3^{\prime}\right)$. Ventral surface of metafemora with longitudinal sinuous carina, nearer anterior edge at base and more distant towards apex...

$5^{\prime}$. Ventral surface of metafemora with either anterior margin (carina) straight and very close to anterior edge all over (sometimes vanishing apically) or with no anterior margin or carina.

6(5). Green body. Longitudinal sinuous carina of metafemora nearly paralleling anterior border in the apical half (Fig. 3A). Metafemur postero-apically lobed at least in males. Pygidium very convex. Canthon (s.I.) cleidecostae sp. nov. (Figs. 1A-D)

6'. Body black. Longitudinal sinuous carina of metafemora basally and apically very close to anterior border, but never parallel to it (Fig. 3B). Metafemur not postero-apically lobed. Pygidium feebly convex

.Canthon (Glaphyrocanthon) (pars, species around C. ibarragrassoi (Martínez, 1952) and species still undescribed)

$7\left(5^{\prime}\right)$. Ventral surface of metafemora not margined anteriorly.

7'. Ventral surface of metafemora with fine margination anteriorly (sometimes vanishing apically)

8(7). Pygidium strongly convex, very shiny. Amazon and Atlantic Forest Canthon (Goniocanthon) Pereira \& Martínez, 1956 (see Nunes et al., 2018)

8'. Pygidium flat or slightly convex, dull or slightly shiny

$9\left(8^{\prime}\right)$. Metafemora elongate, claviform. Atlantic Forest .Canthon (Peltecanthon) Pereira, 1953 (see Nunes et al., in press)

$9^{\prime}$. Metafemora not claviform

$10\left(9^{\prime}\right)$. Dorsum with distinct and dense uniform pubescence, dorsum completely opaque. Body flattened. Protibial teeth closely set near the apex of tibia. Northern Amazonia. .Canthon (Trichocanthon) Pereira \& Martínez, 1959 (monospecific, C. sordidus Harold, 1868)

10'. Dorsum either glabrous or with minute sparse pubescence. Protibial teeth widely spaced along apical half of lateral margin. Widespread, except Chile ....... Canthon (Glaphyrocanthon) Martínez, 1948 (probably to be split)

11. Pygidium and propygidium not separated by transverse carina. South and Central America....... Canthon Hoffmansegg, 1817: septemmaculatus group

$11^{\prime}$. Pygidium and propygidium at least partially separated by transverse carina

12. Head anteriorly either sinuous or slightly emarginated, sometimes without clypeal teeth. Pronotum with prescutellar depression; adjacent area of elytra with scutellar depression. Open areas in Chaco, Pampa, Cerrado and Caatinga...... Canthon (Pseudepilissus) Martínez, 1954 (see Vieira et al., 2019)

12'. Clypeus with at least two (sometimes more) well-defined clypeal teeth. Central teeth separated from each other by narrow emargination. Body usually not depressed around scutellum.

13. Anterior margin of profemora either with one large tooth close to concavity or with several well-defined denticles (inside concavity or not). Brazil, Argentina, Bolivia, Paraguay, Uruguay; not present in Amazonia ...... Canthon (Francmonrosia) Pereira \& Martínez, 1959

13'. Profemora lacking anterior denticles or teeth. Widespread in South America. Canthon s. str. Hoffmansegg, 1817 (to be split). 


\section{Family Scarabaeidae Latreille, 1802 \\ Subfamily Scarabaeinae Latreille, 1802 \\ Tribe Deltochilini Lacordaire, 1856 \\ Genus Canthon Hoffmannsegg, 1817 \\ Canthon cleidecostae sp. nov.}

(Figs. 1-3)

Type material: HOLOTYPE ( $\sigma^{\top}$ CEMT): First label [white, typeset]: "BRAZIL: Goiás, Monte / Alegre de Goiás, / $13^{\circ} 14^{\prime} 10^{\prime \prime} \mathrm{S}, 47^{\circ} 09^{\prime} 19^{\prime \prime} \mathrm{W}$, / 13.iii.2013, Kerodon / acrobata feces, Alexandre / leg.". Second label [red, handwritten]: "Canthon cleidecostae / Vaz-de-Mello, Nunes / \& CostaSilva / HOLOTYPE". PARATYPE (10" CEMT): First label [white, typeset]: "BRAZIL: Goiás, Monte / Alegre de Goiás,

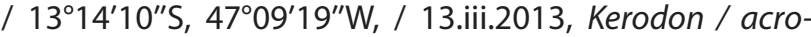
bata feces, Alexandre / leg.". Second label [yellow, handwritten]: "Canthon cleidecostae / Vaz-de-Mello, Nunes / \& Costa-Silva / PARATYPE".
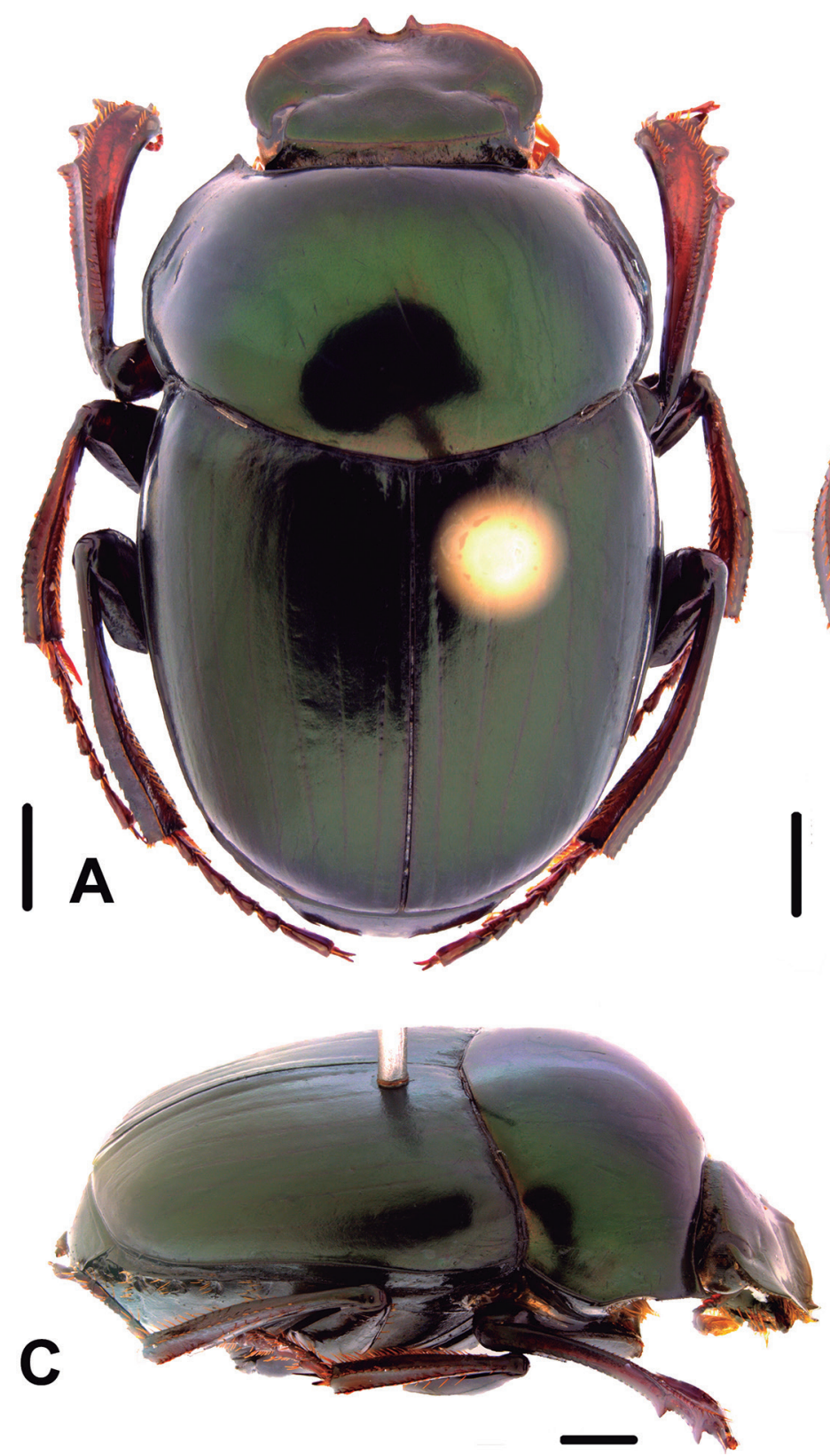

Diagnosis: Canthon cleidecostae sp. nov. is most similar to Canthon ibarragrassoi, with which it shares the metafemora with a sinuous carina close to the anterior margin (Fig. 3). Furthermore, it can be easily separated by the clypeal teeth, which are U-shaped in C. cleidecostae sp. nov. and V-shaped in C. ibarragrassoi. The colour is also characteristic while $C$. cleidecostae sp. nov. is metallic green and C. ibarragrassoi present black colouration.

Description (Holotype, Male): Dorsal habitus (Fig. 1A). Body length (except the head) $7.55 \mathrm{~mm}$. Head: dorsal surface slightly concave with green alveolar microsculpture; posterior half with finely spaced punctation and anterior half with superficial rugosities. Two triangular clypeal teeth, with rounded apex, separated by a U-shaped emargination (Fig. 1D). Clypeal margin and lateral margin of head with yellow setae emanating from underneath. Clypeo-genal suture present and oblique until close to

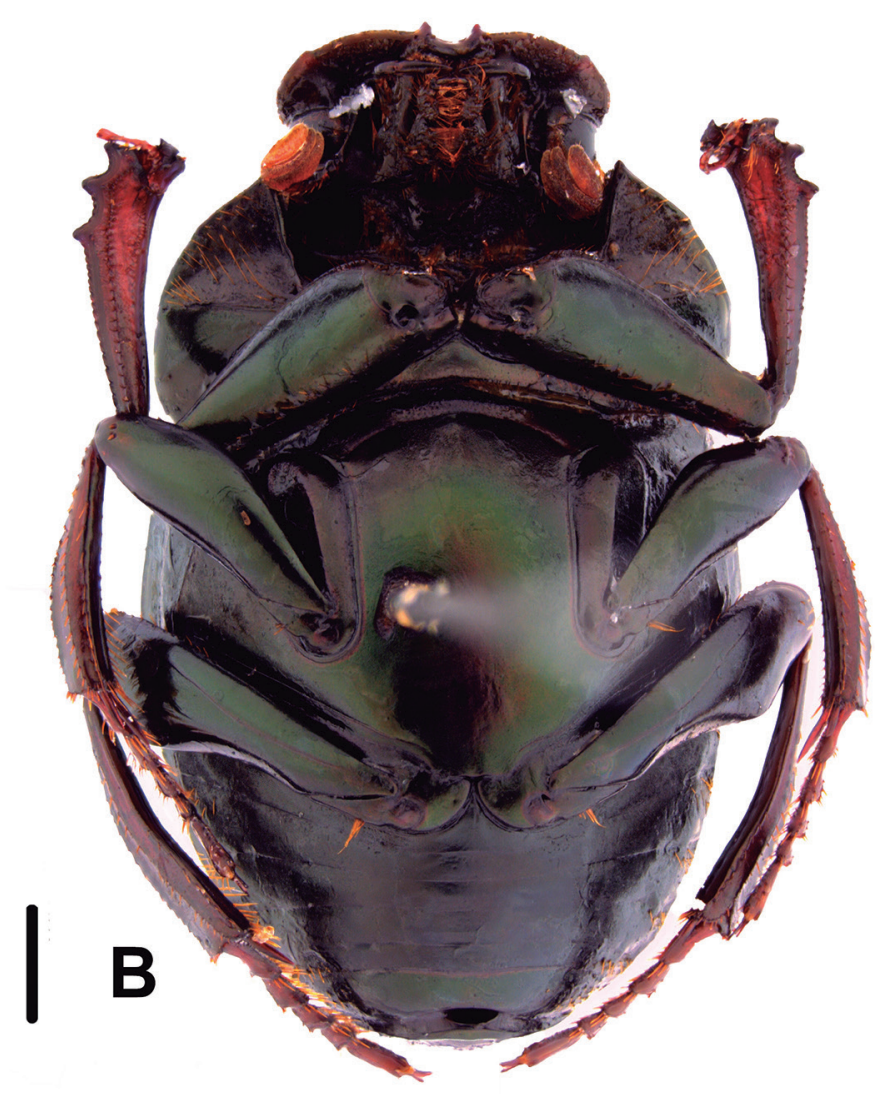

Figure 1. Holotype of Canthon cleidecostae sp. nov.: (A) dorsal; (B) ventral; and (C) lateral view; (D) head, dorsal view. Scale bar: $1 \mathrm{~mm}$. 
eyes. Pronotum: pronotal disc smooth, metallic green, bright with green alveolar microsculpture. Anterior angles acute, pointed forward (Fig. 1C). Lateral margin smooth with two little teeth and brief emargination between them (more visible in lateral view). Hypomeron: dark green, with coriarious microsculpture, sparse yellowish setae anteriorly, and thin transverse carina at centre not touching lateral margin; anterior region slightly concave (Fig. 1B). Elytra: surface with dark green colour, less bright than pronotum; with fine micropuncture. Striae narrow and poorly visible, with punctation; interstriae wide, flat. Legs: protibiae with three main teeth on outer edge and crenulated until the base; protibial spur flattened dorsoventrally, bifid, asymmetrical (Fig. 2A). Mesofemora with ventral side lacking anterior and posterior margin. Metafemora subclaviform, with a sinuous carina (Fig. 3A, white setae); yellow setae on the anterior edge and close to apex; posterior edge with lobe comprising two-thirds apically (Fig. 3A). Abdomen: surface with alveolar microsculpture; dark green. Ventrites with tufts of small yellow setae on each side laterally and medially glabrous (Fig. 1B). Pygidium: as wide as long; bright green without punctation. Basal margin expanded, forming strong V-shaped carina between pygidium and propygidium. Parameres: lateral view: symmetrical; apex truncate (Fig. 2B). Superior edge straight and inferior concave, never sinuous. Apical-laterally edge with bulge at centre. Dorsal view: membranous portion separating parameres from base to apex. Internal sac: peripheral fronto-lateral sclerite (FLP) connected to of the axial sclerite (Ax), both sclerites forming an apical complex, in which Ax forms a central semiduct (Fig. 2E, Ax [black arrow]) and FLP completes the circunference in the semiduct (Ax) (like a roof), base and apex of all the complexes of equal size, without tapered region; subaxial sclerite (SA), about the same size as other sclerites, covering ventrally the FLP $+A x$ complex; peripheral medial sclerite (MP) flat, rolled, with the basal part more acute (in relation to the apex), lateral in relation to FLP + Ax; superior right peripheral sclerite (SRP) with lateral angular prolongation (Figs. 2E-F).

A
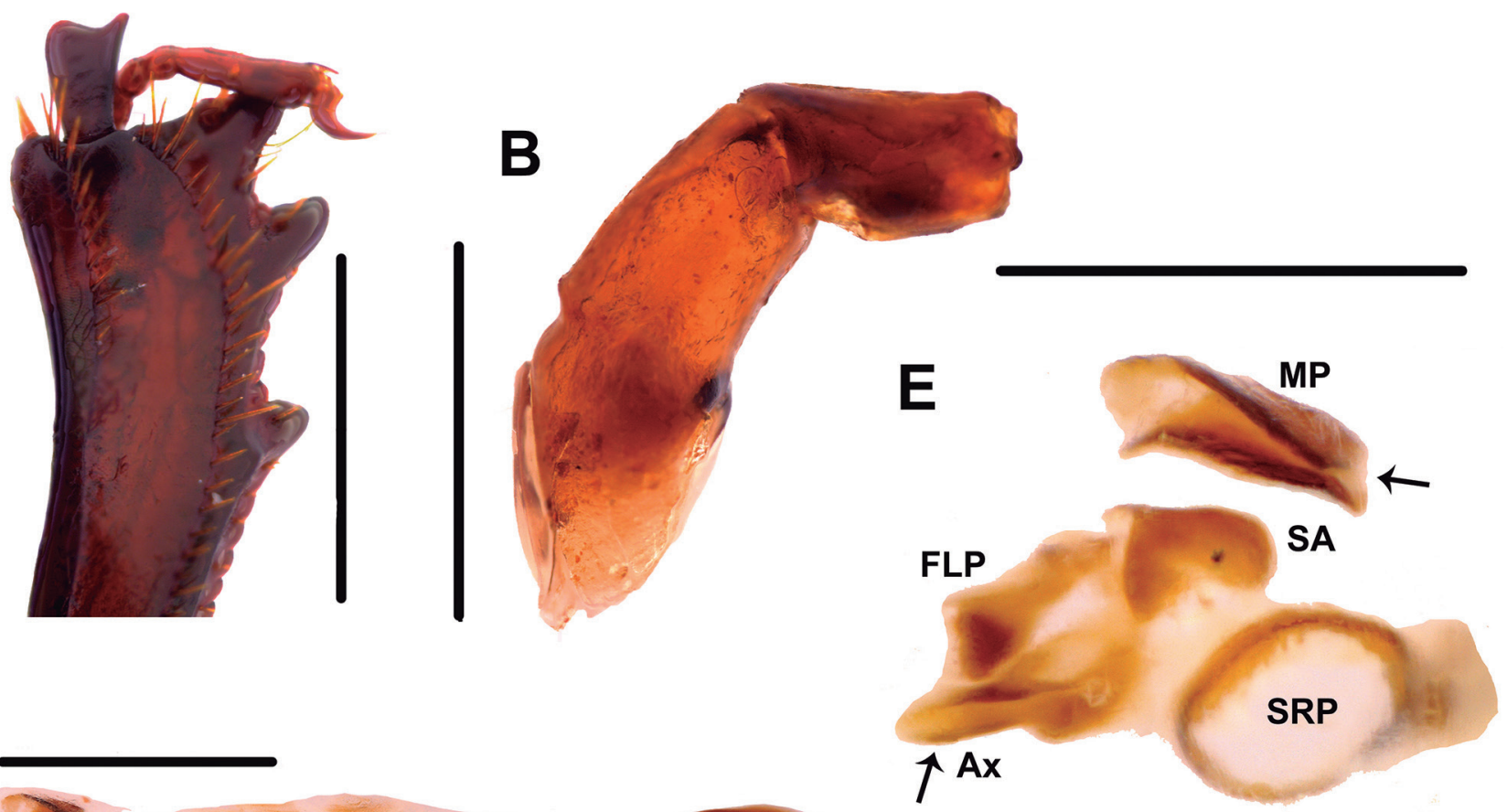

C
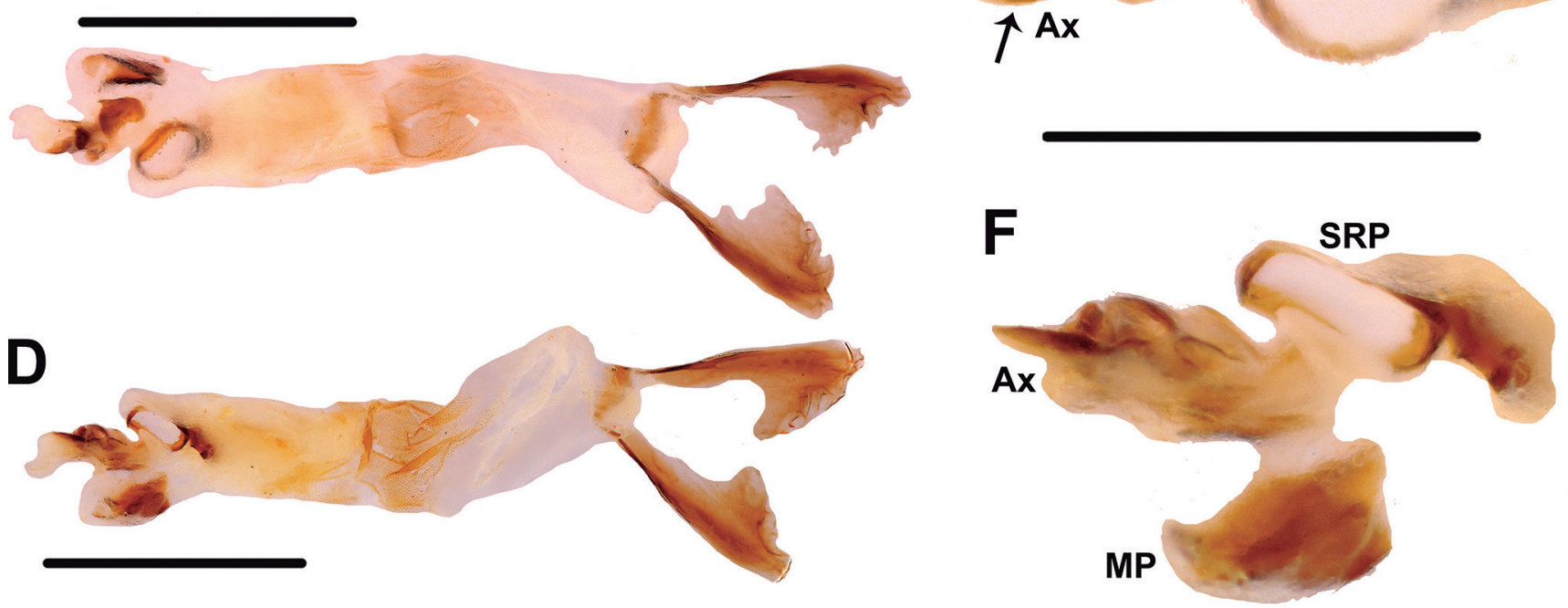

Figure 2. Details of structure in Canthon cleidecostae sp. nov.: (A) male protibial apex, dorsal; Male genitalia: (B) aedeagus, lateral; internal sac: (C) dorsal and (D) ventral views; internal sac apical and parietal sclerites: $(E)$ dorsal and (F) ventral views [ $A x=$ axial sclerite; $F L P=$ fronto-lateral peripheric sclerite; $M P=$ medial peripheric sclerite; $S A=$ subaxial sclerite; $S R P=$ superior peripheric sclerite]. Black arrow showing the semiduct. $S$ cale bars: $A-D=1 \mathrm{~mm} ; E$ and $F=0.5 \mathrm{~mm}$. 
Morphological variation: The variation between the two specimens of the type series is centred on the body length, which varied from $6.05 \mathrm{~mm}$ (paratype) to $7.55 \mathrm{~mm}$ (holotype).

Etymology: This species is named after Dr. Cleide Costa, in acknowledgement of her great contribution to the study of Coleoptera and for supervising many Brazilian coleopterists. An important remark is that the larva of this species is still unknown and we hope it will be described in collaboration with Dr. Costa when available.

Distribution: So far, this species is only known from the type locality (Monte Alegre de Goiás, Goiás state) (Fig. 4).

Biology: Nothing is known about the biology of C. cleidecostae sp. nov. The feeding habits are probably coprophagous, considering related species of the same genus. Besides, the type-series was collected in Kerodon acrobata Moojen, Locks \& Langguth, 1997 faeces, a rodent endemic of Brazil and know only to Goiás state (Woods \& Kilpatrick, 2005).

Comments: The placement of this new species within the subgenera of Canthon is still uncertain. Some morphological characteristics used to describe this species are similar to Canthon ibarragrassoi (Martínez, 1952), mainly considering the sinuous carina in the metafemur.

The geographic distribution of both species is distinct. Canthon cleidecostae sp. nov. is known for the type locality as aforementioned, while Canthon ibarragrassoi is recorded to Paraguay (type locality: Colonia Natalício Talavera), Argentina (Mesopotamia Argentina) and Brazil (Rio Grande do Sul, Santa Catarina, Paraná, São Paulo, Mato Grosso do Sul, Rio de Janeiro, Minas Gerais and Espirito Santo states, the latter state being the northernmost known record of the species.

As currently understood, C. ibarragrassoi belongs to the subgenus Glaphyrocanthon considering many characteristics listed by Halffter \& Martínez (1977: 79).

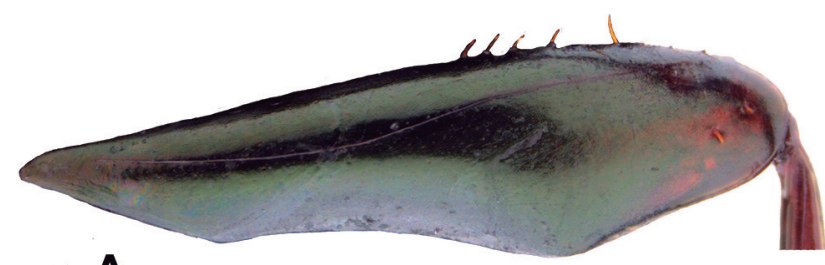

A

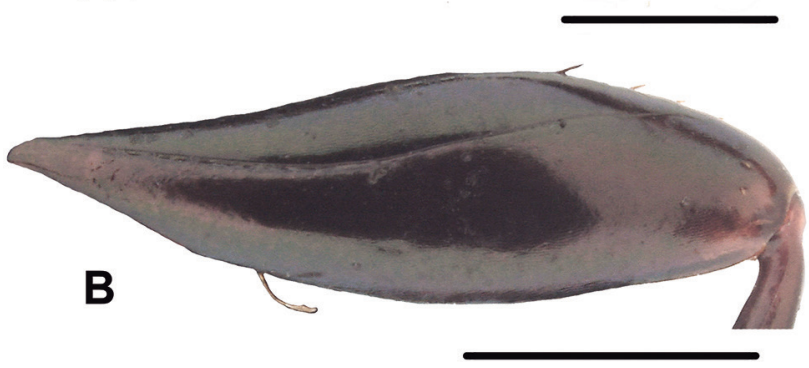

Figure 3. Metafemur, ventral view of (A) Canthon cleidecostae; and (B) Canthon ibarragrassoi. Scale bar: $1 \mathrm{~mm}$.

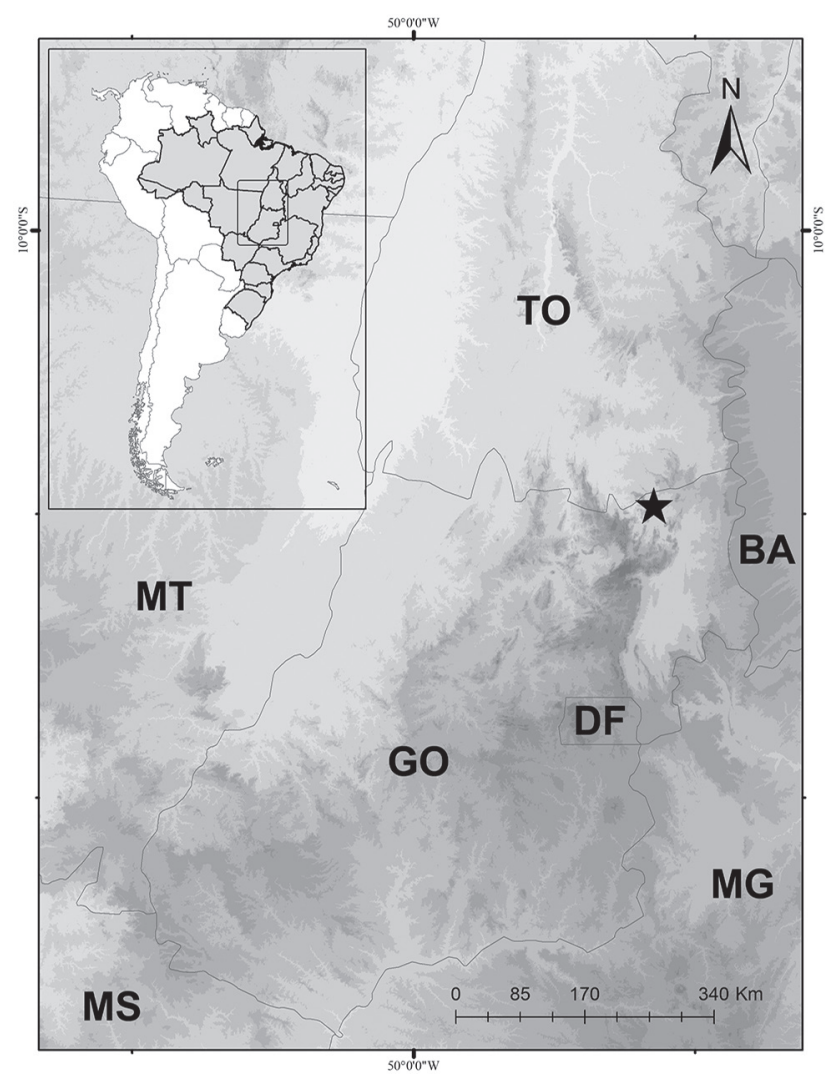

Figure 4. The distribution record of Canthon cleidecostae sp. nov., central Brazil [TO = Tocantins; MT = Mato Grosso; $G 0=$ Goiás; DF = Distrito Federal; $B A=$ Bahia; $M G=$ Minas Gerais; MS = Mato Grosso do Sul $]$.

However, even C. cleidecostae sp. nov. sharing these characteristics with $C$. ibarragrassoi we concluded that the new species should not be included in the Glaphyrocanthon without a detailed taxonomic revision of this subgenus. Thus, to avoid "taxonomic instability", we regard Canthon cleidecostae sp. nov. as incertae sedis.

In addition, the sclerites of the internal sac are not similar to those found in Goniocanthon Pereira \& Martínez, 1956 (Nunes et al., 2018), nor in Peltecanthon (Nunes et al., in press), where the Ax + FLP complex gradually tapers to a much thinner apex, or even other Canthon handled by one of the authors (Nunes, personal remarks). In Canthon cleidecostae sp. nov., the apex is not thin, something similar to that observed in Tetraechma Blanchard, 1845 (Nunes, personal remarks).

\section{ACKNOWLEDGEMENTS}

This study was financed by the Coordenação de Aperfeiçoamento de Pessoal de Nível Superior - Brasil (CAPES) - Finance Code 001. The first author is thankful to CNPq (306745/2016-0). The authors are grateful to CNPq (process no 405697/2013-9 and 484035/2012-4) and Dr. Gimo Daniel (The National Museum of Bloemfontein) for his comments and for improving the English version of the manuscript. The authors also thank the anonymous referee and Mario Cupello to improve the critical process of revision. 


\section{REFERENCES}

Blanchard, C.É. 1845. Insectes de I'Amérique Méridionale. In: d'Orbigny, A.; Blanchard, C.É. \& Brullé, A. Voyage dans l'Amérique Méridionale, Insectes Coléoptères. Tribu des Lamellicornes Paris, P. Bertrand. v. 6, pt 2, p. 155-168.

Cupello, M. \& Vaz-de-Mello, F.Z. 2018. A monographic revision of the Neotropical dung beetle genus Sylvicanthon Halffter \& Martínez, 1977 (Coleoptera: Scarabaeidae: Scarabaeinae: Deltochilini), including a reappraisal of the taxonomic history of 'Canthon sensu lato'. European Journal of Taxonomy, 467: 1-205.

Edmonds, W.D. 1972. Comparative skeletal morphology, systematics and evolution of the phanaeine dung beetles (Coleoptera: Scarabaeidae). The University of Kansas Science Bulletin, 49(11): 731-874.

Halffter, G. \& Martínez, A. 1977. Revisión monográfica de los Canthonina americanos, IV parte. Clave para géneros y subgéneros. Folia Entomológica Mexicana, 38: 29-107.

Harold, E. 1868. Monographie der Gattung Canthon. Berliner Entomologische Zeitschrift, 12: 1-144.

Harris, R.A. 1979. A glossary of surface sculpturing. Occasional Papers in Entomology, 28: 1-31.

Hoffmannsegg, J.C. Graf von. 1817. Entomologische Bemerkungen bei Gelegenheit der Abhandlungen über amerikanische insecten, in der vierten bis sechsten Lieferung von den Recueils d'observations de zoologie et d'anatomie comparée, oder dem 2ten Theile der Reise, der Herren Al. v. Humboldt und A. Bonpland, nemlich: No. IX in Livr. 4. p. 197-283. und No XI. XII. in Livr. 5. 6. p. 294-397. Zoologisches Magazin, 1(1): 8-56.

Martínez, A. 1948. Notas Coleopterologicas I. Anales de la Sociedad Científica Argentina, 146(1): 41-51.

Martínez, A. 1952. Scarabaeidae nuevos o poco conocidos, III. Mision de Estudios de Patologia regional argentina, 23(81-82): 53-118.

Martínez, A. 1954. Scarabaeoidea Neotropical. Neotropica, 1(2): 27-28.

Martínez, A. \& Pereira, F.S. 1956. Dois gêneros novos de Canthonini americanos (Col. Scarabaeoidea, Scarabaeidae). Papéis Avulsos de Zoologia, São Paulo,12: 363-388.

Nunes, L.G. de 0.A.; Nunes, R.V. \& Vaz-de-Mello, F.Z. 2018. Taxonomic revision of the South American subgenus Canthon (Pelthecanthon) Pereira, 1953 (Coleoptera: Scarabaeidae: Scarabaeinae: Deltochilini). European Journal of Taxonomy, 437: 1-31.
Paulian, R. 1938. Contribution a l'étude des Canthonides Américains. Annales de la Société Entomologique de France, 107: 213-296.

Pereira, F.S. 1953. Notas sinonímicas (Col. Scarabaeidae). Dusenia, 4(5-6): 387-402.

Pereira, F.S. \& Martínez, A. 1956. Os gêneros de canthonini americanos (Col. Scarabaeidae). Revista Brasileira de Entomologia, 6: 91-152.

Pereira, F.S. \& Martínez, A. 1959. Tres nuevos géneros de "Canthonini" americanos (Coleoptera, Scarabaeidae). Acta Zoologica Lilloana, 17: 164-184.

Schmidt, A. 1922. 1. Bestimmungstabelle der mir bekannten CanthonArten. 2. Verbreitungsbiete der Canthon-Arten. 3. Neubeschreibungen von Canthon, Saprosites, Mendidius, Euparia und Ataenius. Archiv für Naturgeschichte, 88(3): 61-103.

Schoolmeesters, P. 2018. Scarabs: World Scarabaeidae Database (version Apr 2018). In: Roskov, Y.; Orrell, T.; Nicolson, D.; Bailly, N.; Kirk, P.M.; Bourgoin, T.; DeWalt, R.E.; Decock, W.; De Wever, A.; Nieukerken, E.; van Zarucchi, J. \& Penev, L. (Eds.). Species 2000 \& ITIS Catalogue of Life. Leiden, Naturalis.. Available at: http://www.catalogueoflife.org/col. Access in: 22/09/2019.

Silva, F.A. \& Valois, M. 2019. A taxonomic revision of the genus Scybalocanthon Martínez, 1948 (Coleoptera: Scarabaeidae: Scarabaeinae: Deltochilini). Zootaxa, 4629(3): 301-341.

Tarasov, S.I. \& Génier, F. 2015. Innovative Bayesian and parsimony phylogeny of dung beetles (Coleoptera, Scarabaeidae, Scarabaeinae) enhanced by ontology-based partitioning of morphological characters. PLOS ONE, 10(3): 1-86.

Vaz-de-Mello, F.Z.; Edmonds, W.D.; Ocampo, F. \& Schoolmeesters, P. 2011. A multilingual key to the genera and subgenera of the subfamily Scarabaeinae of the New World (Coleoptera: Scarabaeidae). Zootaxa, 2854: 1-73.

Vieira, M.K.; Vaz-de-Mello, F.Z. \& Silva, F.A. 2019. A taxonomic revision of the Canthon subgenus Pseudepilissus Martínez, 1954 (Coleoptera: Scarabaeidae: Scarabaeinae). Insect Systematics \& Evolution, 1: 1-57.

Woods, C.A. \& Kilpatrick, C.W. 2005. Infraorder Hystricognathi. In: Wilson, D.E. \& Reeder, D.M. (Eds.). Mammal Species of the World: A taxonomic and geographic reference. 3. ed. Baltimore, Johns Hopkins University Press. v. 2, p. 1538-1600.

Zunino, M. 1978. L'armatura genitale negli Onthophagini: tecniche di preparazione e criteri di studio. Linformatore del giovane entomologo. Bollettino della Società Entomologica Italiana, 90: 21-26. 